\title{
Maliye Politikasında Amaç Araç Uyumu: Ücret Vergileri ve Artan Oranlı Tarife Uygulaması Açısından Bir İnceleme
}

\author{
Matching Ends and Means in Fiscal Policy: A Study on Wage \\ Tax and Progressive Tariff Policy
}

\author{
Yrd. Doç. Dr. Deniz Aytaç
}

\begin{abstract}
Öz
Kamu sektörü ekonomi politikaları aracıliğıyla farklı hedeflere ulaşmayı amaçlayabilir. Bu çerçevede hedeflere uyumlu mali politika araçlarının kullanilması gereklidir. Bu mali politika araçlarından biride ücret vergileridir. Bu çalışmada Türkiye'de vergilerin artan oranlılı özelliğinin, gelir dağılımı, istihdam ve kayıtdışl ekonomi ile ilgili hedeflerle uyumu, farkli gelir grupları için, OECD tarafindan kullanilan ve sosyal güvenlik kesintileri, gelir vergisi gibi mali yükümlülükleri içeren ücret vergilerinin artan oranlilı̆̆ ölçülerek incelenmiştir. Vergi sisteminin artan oranlilığ nomik ve sosyal statüye sahip gelir grupları için bakiye gelir artan oranlilik katsayısı ile analiz edilerek elde edilen sonuçlar, OECD tarafinda artan oranlilik incelemelerinde kullanilan vergi kamasının artan oranlilğ ile kıyaslanmışve Türkiye'de vergi kamasının OECD ve AB ortalamasın $\ddot{z} z$ erinde, vergi kaması artan oranlılı endeksinin ise ülke ortalamalarının gerisinde seyrettiği ve mevcut yapısı ile ücret vergileri Türkiye’nin gelir dağllımı, istihdam ve kayıtdışı ekonomi ile ilgili ekonomik hedeflerine uygun olmadiğı sonucuna ulaşılmıştır.
\end{abstract}

Anahtar Kelimeler: Ücret Vergileri, Artan Oranlllk, Vergi Kamasi, Bakiye Artan Oranlilik Endeksi, Vergi Kaması Artan Oranlilık Endeksi

\footnotetext{
Abstract

The public sector may aim to achieve different goals through economic policies. In that context, fiscal policy tools consistent with those goals need to be employed. Wage tax is one of those fiscal policy tools. This study measures and examines harmony between the prog-
}

ressive nature of taxes in Turkey and targets related to distribution of income, employment, and informal economy as well as the progressive rates of wage tax which are used by the OECD and comprise fiscal obligations such as social security deductions, income tax for different income categories. Tax system was analysed for income categories with different economic and social statutes by using residual income progression and then conclusions was compared with tax wedge progression index which was used by OECD and it was concluded that the tax wedge in Turkey is above the average for the OECD and the EU while tax wedge progression index is below the average for different countries and that the current structure of the wage tax is not consistent with Turkey's economic goals such as distribution of income, employment, and informal economy.

Keywords: WageTax, Progroessivity, Tax Wedge, Residual Income Progression Index, Tax Wedge Progression Index

\section{Giriş}

Kamu sektörü ekonomi politikaları aracıllğıyla fiyat istikrarının sağlanması, işsizlikle mücadele ya da iktisadi büyümenin gerçekleştirilmesi gibi farklı alternatif hedeflere ulaşmayı amaçlayabilir. Bu çerçevede ulaşılmak istenen hedeflere uyumlu olarak farklı mali politika araçlarının kullanılması gerektiği açıktır. $\mathrm{Bu}$ anlamda ücretler üzerindeki mali yükümlülükleri belirleyen ve işgücü piyasası üzerinde etki/ler yaratan

Yrd. Doç. Dr. Deniz Aytaç, Hitit Üniversitesi İ̈BF, aytac.deniz@gmail.com 
temel politika araçları; vergi ve sosyal güvenlik alanlarıyla ilgilidir. Bu alanda iktisadi aktörler üzerindeki mali yükümlülükler; istihdam üzerindeki gelir vergisi ve sosyal güvenlik primlerinden oluşmaktadır. $\mathrm{Bu}$ mali yükümlülükler özellikle istihdam düzeyi, istihdamın niteliği, kayıtdışı ekonominin büyüklüğü ve gelir dağılımı gibi ekonomik değişkenler üzerinde etkiler yaratmaktadır. Bu nedenle söz konusu mali yükümlülüklerden oluşan bir sistemin belirlenen hedeflerle uyumlu olarak taşıması gerekli nitelikleri bulunmaktadır. Bireylerin ödeme güçleri ile ilişkilendirilen adil bir vergileme ile sosyal amaçlar doğrultusunda gelirin yeniden dağılımı hedeflendiğinde mali yükümlülüklerden oluşan sistemin artan oranlı bir yapıya sahip olması önerilir. Fakat önerilen artan oranlılık özelliği bir çok gelişmekte olan ülkede olduğu gibi sadece vergi dilimlerinin arttırılması ile sınırlı kalmakta yada vergi harcamaları ile sistem artan oranlı yapısından uzaklaşmaktadır. Bu uzaklaşma nedeni ile görünürde kalan artan oranlılık özelliği bir taraftan sosyal adalet kapsamında gelirin yeniden dağlımına hizmet edemez hale gelirken, diğer taraftan uygulanan mali yükümlülükler ve özellikle vergiler nedeni ile bireylerin vergi öncesi ve vergi sonrası geliri arasındaki fark giderek açılmakta, diğer bir ifade ile vergi kaması (takozu) (tax wedge) artarak, istihdam ve kayıtdışı ekonomi bu durumdan olumsuz etkilenmektedir. Böylece gerçekte artan oranlı olmayan bir sistemin ekonomiye getirdiği maliyet, iktisadi hedeflerden uzaklaşılması olmaktadır.Vergi uygulamaları ile gelir dağılımında hedeflenen eşitliğin ve sosyal adaletin ne oranda sağlanabildiği ise sitemin sahip olduğu artan oranlılık derecesine bağlıdır ve bu derece, farklı artan oranlılık endeksleri ile ölçülmektedir.Bu çalışmada, Türkiye'de vergilerin artan oranlılık özelliğinin, gelir dağılımı, istihdam ve kayıtdışı ekonomi ile ilgili hedeflerle uyumlu olup olmadığ 1 sorusuna, farklı gelir grupları için, OECD tarafından kullanılan ve sosyal güvenlik kesintileri, gelir vergisi gibi mali yükümlülükleri içeren ücret vergilerinin (wage tax) artan oranlılı̆̆

Bu doğrultuda çalışmada ilk olarak konu ile ilgili teorik çerçeve ve vergi sistemlerinin artan oranlılı̆̆ının hesaplanmasında kullanılan yöntemler ele alınacak, ilgili literatür incelendikten sonra uygulama aşamasında vergi sisteminin artan oranlılı̆g farklı ekonomik ve sosyal statüye sahip gelir grupları için bakiye gelir artan oranlılık katsayısı (coefficient of residual income progression) ile analiz edilerek elde edilen sonuçlar, OECD tarafında artan oranlılık incelemele- rinde kullanılan vergi kamasının artan oranlılığı (tax wedge progressivity) ile kıyaslanacaktır. Sonuçta ekonomik ve sosyal hedeflerle kullanılan araçların sahip olduğu özelliklerin uyumluluğu incelenerek, elde edilen bulgular OECD ve Avrupa Birliğine üye 15 ülke ortalaması (AB 15) ile karşılaştırılacaktır.

\section{Teorik Çerçeve ve Artan Oranlılık Endeksleri}

Bir vergi sisteminde alt gelir gruplarından, üst gelir gruplarına doğru hareket edildiğinde ortalama vergi oranının artması vergide artan oranlılık olarak tanılanmaktadır (Musgrave ve Thin, 1948, s.498).Sosyal adalet ve finansman açısından gelir vergileri ve gelir vergilerinin oransal yapısı özellikle gelişmekte olan ülkelerde hükümetler için en uygun politik enstrümanların başında gelir. Bu yüzden birçok gelişmekte olan ülkede çoklu vergi dilimi uygulaması ile gelir vergisi nominal olarak artan oranlı bir yapıya kavuşturulmaya çalışılmaktadır. Fakat etkin artan oranlılık uygulaması özellikle gelişmekte olan ülkelerde yüksek gelir grupları lehine uygulanan indirimler, muafiyetler ve istisnalar nedeni ile olumsuz etkilenmekte ayrıca etkin artan oranlılık uygulaması vergi dilimi sayısının arttırılması ile sağlanmaya çalışıldığından vergi sisteminin artan oranlılığ sadece görünürde kalmaktadır (Tanzi ve Zee, 2000, s. 15-16). Sistemin sadece görünürde kalan artan oranlılığı, ülkelerin gelir dağılımında sosyal adaletin sağlanması hedeflerini olumsuz etkilemektedir. Diğer yandan vergi uygulaması nedeni ile üretim yada faaliyetlerden elde edilen hizmetlerin veya faktörlerin vergi öncesi ve vergi sonrası fiyatları arasında vergi takozu(vergi kaması) (tax wedge) meydana gelmekte (Arıkan ve Bahçe,2011, s. 31) ve meydana gelen vergi takozu bir taraftan istihdam ve kayıt dışı ekonomi ile ilgili ekonomik hedefleri olumsuz etkilerken, diğer taraftan vergi takozunun gelir grupları arasındaki dağılımı, bölüşümdeki eşitlik hedefini de engelleyebilmektedir. Nitekim yapılan ampirik çalışmalarda bu sonucu destekler niteliktedir. Nickell ve Layard (1999) çalışmalarında sosyal güvenlik kesintilerini kapsayan ortalama vergi kamasındaki $\% 5^{\prime}$ lik bir düşüşün, işsizliği $\% 13$ oranında azaltılacağı belirtilmiştir. Alesina ve Perotti (1997) 14 OECD ülkesi için yaptıkları çalışmada ücret vergilerindeki artışın, birim işgücü maliyetlerini artırdığı ve rekabeti olumsuz etkilediği sonucuna varmışlardır. Ayrıca çalışmada rekabetteki bu düşüşün ihracatı olumsuz etkileyerek uzun vadede işgücünü azalttığı 
tespit edilmiştir. Daveri ve Tabellini (2000) çalışmalarında ise ücret vergileri ile istihdam ve büyüme arasinda negatif bir ilişkinin olduğunu belirtmişlerdir. Gora vd. (2006) yılında 8 Avrupa Birliği üye ülkesini kapsayan çalışmalarında, vergi kamasının özellikle vasıfsız işgücünün istihdamı üzerinde olumsuz etkisinin olduğunu saptamışlardır.

$\mathrm{Bu}$ bulgular 1şı̆̆ında ülkelerin iktisadi ve mali hedeflerine ulaşmada, hedefler ve araçlar arasında uyumun sağlanması için,önemli bir araç olarak kullanılan vergilerin neden olduğu vergi kamasının ve sistemin artan oranlılı̆̆ının tespiti diğer bir ifade ile ölçümü iktisadi mali politikalara yön verilmesi açısından önem arz eder.

\section{İlgili Literatür}

Bu çalışmanın temel noktası ücret vergilerindeki artan oranlılığın yapısı itibari ile gelir dağılımı ve kayıtdıșı istihdamla mücadele gibi politika hedefleri ile uyumlu olup olmadığının araștırılmasıdır.

$\mathrm{Bu}$ noktada ücretler üzerindeki vergilerin artan oranlılı̆̆ 1 gelir vergisi ile sosyal sigorta kesintilerinin düzenlenmesi ve aralarındaki etkileşimle yakından ilgilidir. Bireysel gelir vergisini artan oranlılığ 1 ise vergi dilimi sayısına, yüksek ve düşük vergi oranları arasındaki farka diğer bir ifade ile gelir vergisi sedülüne dayanır. Gelir düzeyini ve aile yapısını dikkate alarak yaratılan vergi istisna ve muafiyetleri ile sınırlanan vergi mükellefiyeti, gelir vergisi artan oranllığını etkileyen bir diğer unsurdur. Ücret üzerindeki kanuni mükellefiyet bireysel gelir vergisi dışında, çalışan ve işveren için sosyal güvenlik primlerini de kapsamaktadır. Bu bağlamda ele alındığında, gelir vergisinden farklı olarak, sosyal güvenlik primleri genellikle düz oranlı olmakta ve vergi sisteminin artan oranlı yapısını düşürebilmektedir. Bu genel değerlendirme içinde bireysel gelir vergisi ve sosyal güvenlik primlerinden oluşan ücret vergilerinin artan oranlılığının ölçümü, farklı göstergelere dayanmaktadır. $\mathrm{Bu}$ göstergeler,efektif artan oranlilık ve yapisal artan oranlılık göstergeleridir. Söz konusu göstergeler arasındaki temel farklılaşma yapılan ölçümün kapsamından ve kullanılan verilerden kaynaklanmaktadır. Efektif artan oranlllık göstergesi, bireysel gelir vergisini, sosyal sigorta primlerini, dolaylı vergileri, nakdi ve ayni yardımları kapsayan vergi sisteminin, artan oranlılığının ölçerken, yapısal artan oranlılık göstergesi daha izole bir yöntemle sadece bireysel gelir vergisi ve sosyal güvenlik primlerini kapsamaktadır. Artan oranlılık göstergeleri arasındaki farklar kullanılan veriler açısından ele alındığında, efektif artan oranlılık gösterge hesaplamalarında hanehalkı anketleri tercih edilmekte böylece hanehalkının vergi öncesi ve sonrasi gelirine ait veriler hesaplamalara dahil edildiği görülmektedir. Yapısal artan oranlılık göstergelerinde ise hane halkı anketlerinin kullanımının yarattığg temel sorunlar (anketlerin nüfusun tamam1nı kapsamaması ve uçlardaki gelir gruplarının anket dışında kalabilme olasılığı) nedeni ile kanuni vergi oranları sedülü (statutory tax rate schedule) kullanılmaktadır (Paturoit vd., 2013, s. 4-6).

Artan oranlllık göstergelerindeki söz konusu iki temel ayrıma ek olarak,1940'ların sonlarından bu yana vergide artan oranlılığın ölçülmesinde farklı endekslerin kullanımı söz konusu olmuştur (Musgrave ve Thin, 1948; Kakwani, 1977; Suits, 1977; Khetan ve Poddar, 1976; Pechman ve Okner, 1974; Reynolds ve Smolensky, 1977; Baum, 1987, 1988; Aggarwal, 1994)). Tüm bu farklı endeksleri Duclos ve Tabi (1996) iki grup altında sinıflandırmaktadır. Bu gruplardan ilki vergi payı yaklaşımı, diğeri ise yeniden dağılım yaklaşımıdır. Kakwani (1977) ve Suits (1977) tarafından ileri sürülen ilk yaklaşıma göre artan oranlılık, değişen brüt gelire (vergi öncesi gelir) bağlı olarak birimler arasında vergi yükünün dağılım payı olarak değerlendirilir ve yoksullara düşen vergi yükü ne kadar azsa vergi sisteminin o kadar artan oranlı olduğu ileri sürülür. Tüm bireylerin vergi yükü iki katına çıkarıldığında bireysel vergi yükü değişmediğinden bu yaklaşımda artan oranlılık ölçümlemelerinin temeli vergi seviyelerinin sıfır dereceden homojen olmasına dayanır ve bu ölçümler vergi yüklerindeki eş orantılı değişimlere karşı duyarsızdır (Duclos ve Tabi, 1996, s. 165).

Yeniden dağılım yaklaşımı olarak adlandırılan ikinci yaklaşım ise Musgrave ve Thin'in 1948 yılındaki çalışmalarına dayanmaktadır ${ }^{1}$. Bu yaklaşım yapısal artan oranlılık göstergesini benimsemektedir. Söz konusu endekste, artan oranlılık, vergilerin yeniden dağıtıcı, diğer bir ifade ile vergilerin vergi sonrası net geliri eşitleme etkisine bağlıdır ve sabit bir brüt gelir dağılımında, vergi sisteminin artan oranlılığı yükseldikçe, net gelir dağılımı daha eşit bir hal almaktadır (Duclos

1 Lim ve Yhun (2004) çalışmalarında yeniden dağılım yaklaşımı sinıflandırmasina Pechman ve Oknar,1974; Reynolds ve Smolensky,1977; Baum,1987,1988; Aggarwal,1994 indekslerini de dahil etmiştir. 
ve Tabi, 1996, s. 165). Bu noktadan hareketle Musgrave ve Thin (1948) tarafından artan oranlılık ölçüsü olarak tanımlanan bakiye gelir artan oranlılık katsay1s1 (coefficient of residual income progression) belli bir gelir düzeyinde sabit oranlı vergi fonksiyonundan sapmaları gösterir (Blackorby ve Donaldson, 1984, s. 684). Jacobsen (1976) ise söz konusu artan oranlllık ölçüsünün görece artan oranlıllğıın en iyi ölçütü olduğunu belirtir. Jacobsen (1976); bu ölçüte göre bir vergi sistemi diğerinden daha artan oranlı ise Lorenz kriterine göre daha fazla yeniden dağıtım işlevine de sahiptir tespitinde bulunur.

$\mathrm{Bu}$ açılklamalar doğrultusunda bakiye gelir artan oranlılık katsayısı:

$$
\frac{1-t^{m}}{1-t^{a}}(1)
$$

olarak tanımlanır. $\mathrm{Bu}$ ifadede $\mathrm{t}^{\mathrm{m}}$ marjinal vergi oranın $1, t^{a}$ ise ortalama vergi oranın 1 temsil etmektedir. Bu doğrultuda hesaplanacak olan bakiye gelir artan oranlılık katsayısı l'e eşit ise vergi sistemi tamamı ile düz oranlı olacak, oran 1'den küçük oldukça sistemin artan oranlllı̆̆ 1 artacaktır (Sorensen, vd., 1997, s. 225).

$\mathrm{Bu}$ anlatılanlar ışığında iki temel artan oranlılık ölçümlemesinin farklarının başında, vergi öncesi ve vergi sonrası net geliri eşitleme prensiplerindeki ayrım gelmektedir. Bu kapsamda farklılaşmanın vergi kamasının dikkate alınıp, alınmaması noktasında doğduğu ileri sürülebilir. Vergi kamasının varlığı ve büyüklügü ise iktisadi birimlerin ekonomik kararlarını etkileyerek istihdam, kayıt dışı ekonomi ve gelir dağılımı üzerinde etkili olabilmektedir. Bu doğrultuda OECD, Musgrave ve Thin (1948)'nin bakiye gelir artan oranlılık katsayısının bir yorumu olarak (Kosi, Bojnec, 2009, s. 5) ifade edilebilecek vergi kamasinın artan oranlıllğ 1 (tax wedge progressivity) hesaplamasinı ekonomik incelemelerine dahil etmeye başlamıştır (OECD, 2007a, s. 171-172). Bu noktada vergi sisteminin artan oranlılı̆ğ dışında, vergi kamasının artan oranlılığı, diğer bir ifade ile kamanın düşük gelir gruplarında, yüksek gelir gruplarına oranla ne kadar düşük olduğunun bilinmesi (OECD: 2007, s. 171) de gelir dağılımı ve istihdam hedefleri açısından önemli bir göstergedir. .Bu göstergenin çalışmaya dahil edilmesindeki temel neden bakiye gelir vergisi artan oranlılık katsayısına göre bir vergi sistemi artan oranlı olarak kabul edilmesi halinde, istihdam ve buna bağlı olarak değişen gelir grupları arasında vergi kamasının dağılımının söz konusu sonuçlarla tutarlı olup olmadığının tespitidir.

$\mathrm{Bu}$ noktada öncelikle vergi kamasının artan oranl1lığının açılklanmasında yarar vardır. OECD yayınlarında vergi kaması artan oranlıllğını hesaplarken, çalışanları elde ettikleri gelire göre ortalama gelirin yüzdesi olarak ifade edilen gelir gruplarına ayırmakta ve hesaplamada en üst ve en alt gelir grubunun vergi kamalarının oranlamasını kullanmaktadır.

$$
\frac{(T W 167-T W 67)}{T W 167}(2)
$$

Bu ifadede TW vergi kamasını, 167 ve 67 ise çalışan$\operatorname{ların}^{2}$ ortalama ücret yüzdesini göstermektedir. $\mathrm{Bu}$ eşitlik doğrultusunda elde edilen sonuç,vergi kamasının düşük gelir grubuna tabi çalışanlarda, yüksek gelir gruplarına kıyasla, yüzde (\%) olarak ne oranda azaldığını göstermektedir (OECD, 2007, s. 171). Böylece vergi uygulaması öncesi ve sonrası doğan farkın gelir grupları arasındaki dağılımı, farklı gelir gruplarının vergilemeden nasıl etkilendiği konusunda ek bilgi elde edilebilmesini sağlamaktadır.

Bu çalışmada, yapısal artan oranlılık göstergelerinden hareketle, farklı gelir grupları için, OECD tarafından kullanılan ve sosyal güvenlik kesintileri, gelir vergisi gibi mali yükümlülükleri içeren ücret vergilerinin ${ }^{3}$ (wage tax) artan oranlılığı ölçülerek, ücretler üzerindeki vergilerin gelir dağılımı ve istihdama etkilerinin incelenmesinde öncelikle Türkiye, OECD ve Avrupa Birliği için bakiye gelir artan oranlılık katsayısı ardından, vergi kaması artan oranlılığı hesaplanarak, yapılacak karşılaştırmalar doğrultusunda ekonomik hedeflere ulaşma konusunda bir politika önerisi oluşturulacaktır.

\section{Uygulama ve Değerlendirme}

Türkiye özeli ele alındığında orta ve uzun vadedeki istihdam, kayıt dışı ekonomi ve gelirin yeniden dağılımı konularındaki hedeflerimizi 9. Kalkınma Planı (2007-2013) ve Özel İhtisas Komisyonu Raporları kapsamında kısaca inceleyecek olursak: kayıtdışı iş-

2 İmalat sanayinde Ortalama Ücretin \%67 ve \% 167'si oranlarını temsil etmektedir.

3 Ücret vergileri terimi ülkemizde kullanılmamakla birlikte, literatürde sıklıkla kullanılmakta ve genel anlamda ücretler üzerindeki sosyal güvenlik kesintileri, gelir vergisi gibi mali yükümlülükleri gibitüm mali yükleri kapsayan bir kavram olarak ifade edilmektedir. 
letme, kişi ve çalışanların kayıt altına alınabilmesini teminen kayıtlı sistemin güçlendirilmesi, ișsizliğin azaltılması ve işgücü piyasasının etkinleştirilmesi sağlanması, yoksulluk ve gelir dağılımındaki dengesizliklerin kalıcı bir şekilde azaltılması, hem vergi politikaları hem de transfer politikalarıyla gelir dağılımının iyileştirilmesi hedeflerinin yer aldığını görürüz.

Burada üzerinde durulacak nokta vergi sisteminin bu hedefleri destekler nitelikte olup olmadığıdır. İlk aşamada yoksullukla mücadele ve gelir dağılımının iyileştirilmesi hedefleri ele alındığında, daha öncede değinildiği üzere, bireylerin ödeme güçleri ile ilişkilendirilen adil bir vergileme ile sosyal amaçlar doğrultusunda gelirin yeniden dağılımı hedefi söz konusu olmaktadır. Bu kapsamda, mali yükümlülüklerden oluşan sistemin artan oranlı bir yapıya sahip olması önerildiğinden, ücretler üzerindeki mali yükümlülüklerin (gelir vergisi + sosyal sigorta primleri)artan orantılı bir yapı içinde olup olmadığı incelenmelidir.

Bu noktada çalışmada öncelikle Türkiye'nin 19982011 yllları arasinda gelir vergisi ve sosyal sigorta primlerinden oluşan ücret vergisi sisteminin artan oranlılığının, bakiye gelir artan oranlılık katsayısı ve vergi kaması artan oranlılığ 1 metotları yardımı ile ele alınacaktır.Çalışmamızda da kullanacağımız yeniden dağılım yaklaşımının ilk uygulaması olan efektif artan oranlılı̆ga dayanan bakiye gelir artan oranlılık katsayısı daha öncede değinildiği gibi ilk olarak Musgrave ve Thin (1948) tarafindan kullanilmış, takiben Jacobsen (1976), Duclos ve Tabi (1996), Sorensen (1999), Brunello ve Soneda (2007), Boeters (2009) çalışmalarında vergi sisteminin tümünün artan oranlılığının hesaplanmasında bu endeksten yararlanmışlardır.Yine aynı endeksi kullanmakla birlikte diğer çalışmalardan farklı olarak Sorensen, Chiristiansen ve Dolado (1997) ve Kosi ve Bojnec (2009), çalışmalarında,OECD ülkeleri için çalışanların ortalama gelirin belli bir yüzdesi olarak gelir gruplarına ait ücret vergilerinin artan oranlllık endeksini ayrı ayrı hesaplamışlardır.

Türkiye için yapılan çalışmalarda ise Selim ve Şenesen (1999) gelir vergisinin artan oranlılığını vergi sisteminin tümü için,1960-1986 yılları arasında Musgrave-Thin etkin artan oranlllık ve Suits, Khetan Poddar, Kakwani endeksleri doğrultusunda incelemişler, Ünlükaplan (2011) ise Türk Vergi Sisteminde 1924-2008 yıllarını kapsayan sekiz farklı dönem için Kakinaka-Pereira yöntemini kullanarak artan oran- lılık endeksini hesaplamış ve her iki çalışmada gelir vergisi sisteminin artan oranlı bir yapıda olduğu sonucuna varılmıştır.

Bu çalışmada ise OECD’nin ortalama gelirin yüzdesi olarak gruplandırdığı gelir grupları için ayrı ayrı ücret vergilerinin artan oranlılığının ölçülmesinde, Musgrave ve Thin'in 1948 yılındaki çalışmalarında kullandıkları yöntem tercih edilmektedir. Tüm diğer çalışmalardan farklı olarak ise bu çalışmada bakiye gelir artan oranlılık katsayısına ek olarak, Türkiye için en üst ve en alt gelir grubu arasında vergi kamasının dağılımının eşitlikçi olup olmadığı ise vergi kaması artan oranlılık katsayısı ile incelenecek ve sonuçlar Avrupa Birliği ve OECD ülke ortalamaları ile karşılaştırılacaktır.

Bu bağlamda Türkiyede 1998-2011 yılları arasında vergi sisteminin artan oranlılığı denklem (1) doğrultusunda hesaplanmıştır. Çalışmada Sorensen, Chiristiansen ve Dolado (1997) ve Kosi ve Bojnec (2009) çalışmalarında olduğu gibi bakiye gelir artan oranlılık katsayısı uygulaması, çalışanların ortalama gelirin belli bir yüzdesi olarak gelir gruplarının ekonomik ve sosyal statüleri göz önüne alınarak aile odaklı (evli, bekar, çocuklu ve çocuksuz) olarak yapılacaktır. Bu doğrultuda hesaplanan bakiye gelir artan oranllık katsayıları Tablo 1'de yer almaktadır.

Yukarıda değinildiği üzere bakiye gelir artan oranlılık katsayısı l'e eşit ise vergi sistemi tamamı ile düz oranlı olacak, oran 1'den küçük oldukça sistemin artan oranlılığ 1 artacaktır. Tablo 1'de elde edilen sonuçlar bu doğrultuda değerlendirildiğinde, 2000 yılından itibaren katsayılar 1'in altında seyrettiğinden sistem artan oranlı olarak nitelendirilebilir ve bu sonuçlar gelir vergisi sisteminin artan oranlı olarak tespit edildiği Selim, Şenesen (1999) ve Ünlükaplan (2011) çalışmaları ile paraleldir. Fakat bu noktada önemli olan, belirlenen makro ekonomik hedeflere sistemin mevcut yapısı ve artan oranlılık katsayısı ile ulaşılıp ulaşılamayacağı, diğer bir değişle farklı sosyal statüdeki gelir grupları için sistemin değerlendirilmesidir. Bu doğrultuda Türkiye için ücretler üzerindeki vergilerin artan oranlılı̆g 1 ortalama gelirin $\% 67, \% 100$ ve \%167'sini kazanan bekar çalışanlar için 2000 yılından itibaren görece olarak düşükte olsa artan oranlı bir yapıya kavuşmuş ve katsayı yıllar itibari ile düşerek sistemin artan oranlılık özelliği bir ölçüde yükselmiştir.Bu noktada dönemler itibari ile değişen vergi oranları ve dilimlerini incelemekte yarar vardır.Gelir 


\begin{tabular}{|c|c|c|c|c|c|c|c|c|c|c|c|c|c|c|c|c|c|c|c|}
\hline 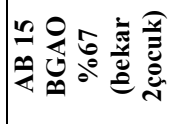 & $\begin{array}{l}8 \\
0 \\
0\end{array}$ & 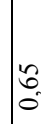 & & $\begin{array}{l}\hat{0} \\
0 \\
0\end{array}$ & $\begin{array}{l}0 \\
0 \\
0\end{array}$ & 8 & & है? & $\overrightarrow{0}^{\circ}$ & $\tilde{O}$ & & 8 & ${ }_{0}^{8}$ & in & के & & 8 & So & \\
\hline 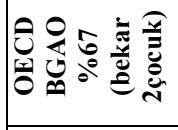 & $\begin{array}{l}\infty \\
0 \\
0 \\
0\end{array}$ & : & & $\tilde{\sigma}_{0}$ & E. & $\sqrt{6}$ & & : & 悉 & : & & 8 & $\begin{array}{l}5 \\
0 \\
0\end{array}$ & 8 & $\mid \begin{array}{l}8 \\
0 \\
0\end{array}$ & & 8 & : & \\
\hline 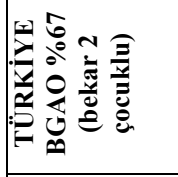 & 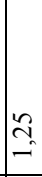 & సે & & के & वे & $1 \ddot{2}$ & & $\begin{array}{c}\text { s. } \\
\text { s. }\end{array}$ & on & $\because$ & & : & $\ddot{\partial}$ & $\begin{array}{l}\infty \\
\infty \\
0 \\
0\end{array}$ & $\begin{array}{l}\infty \\
\infty \\
0 \\
0\end{array}$ & & 8 & $\begin{array}{l}\infty \\
\infty \\
0 \\
0\end{array}$ & \\
\hline 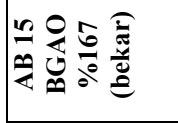 & $\begin{array}{l}0 \\
0 \\
0\end{array}$ & $\begin{array}{l}n \\
8 \\
0\end{array}$ & & $\begin{array}{l}5 \\
0 \\
0\end{array}$ & $\begin{array}{l}\mathcal{O} \\
0 \\
0\end{array}$ & 8 & & $\begin{array}{l}n \\
\text { nू } \\
\text {. }\end{array}$ & $\mathbb{\sigma}_{0}$ & : & & 8 & $\begin{array}{l}8 \\
0 \\
0\end{array}$ & $\begin{array}{l}n \\
\text { n. }\end{array}$ & के & & 8 & 茴 & \\
\hline 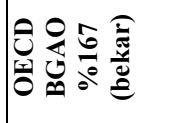 & \&. & $\begin{array}{l}0 \\
0 \\
0\end{array}$ & & $\begin{array}{l}\infty \\
\infty \\
0 \\
0\end{array}$ & $\begin{array}{l}n \\
\infty \\
0 \\
0\end{array}$ & $\mid \begin{array}{l}\infty \\
\infty \\
0\end{array}$ & & $\begin{array}{l}3 \\
\infty \\
0 \\
0\end{array}$ & {$\left[\begin{array}{l}n \\
\infty \\
0 \\
0\end{array}\right.$} & $\begin{array}{c}\infty \\
\infty \\
0\end{array}$ & & 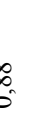 & g. & $\begin{array}{l}\infty \\
\infty \\
0 \\
0\end{array}$ & $\begin{array}{l}\infty \\
\infty \\
0 \\
0\end{array}$ & & 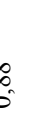 & के & \\
\hline 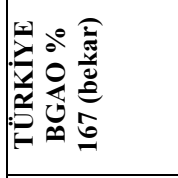 & $\stackrel{0}{0}$ & $\delta$ & & \pm & 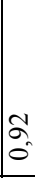 & $\hat{\delta}$ & & $\begin{array}{l}+ \\
0 \\
0\end{array}$ & to & 苾 & & है & $\bar{\sigma}$ & $\begin{array}{l}\infty \\
0 \\
0\end{array}$ & $\begin{array}{l}\infty \\
\infty \\
0 \\
0\end{array}$ & & 8 & $\begin{array}{l}\infty \\
a_{0}\end{array}$ & \\
\hline 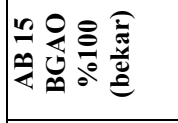 & $\begin{array}{l}\infty \\
\infty_{0} \\
0_{0}\end{array}$ & $\begin{array}{l}+ \\
\vdots \\
0 \\
0\end{array}$ & & $\begin{array}{c}\infty \\
\infty \\
0 \\
0\end{array}$ & बू & $\mid \begin{array}{l}\not \\
\infty \\
0\end{array}$ & & $\begin{array}{l}\circ \\
\infty \\
0 \\
0\end{array}$ & $\begin{array}{l}+ \\
\infty \\
0 \\
0\end{array}$ & $\begin{array}{l}\vec{\infty} \\
0 \\
0\end{array}$ & & $\begin{array}{c}0 \\
0 \\
0\end{array}$ & $\begin{array}{l}\infty \\
\infty \\
0 \\
0\end{array}$ & $\begin{array}{l}\infty \\
\infty \\
0 \\
0\end{array}$ & $\begin{array}{l}\mathcal{N} \\
0 \\
0\end{array}$ & & 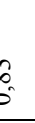 & $\mid \begin{array}{l}t \\
\infty \\
0 \\
0\end{array}$ & \\
\hline Uి & $\begin{array}{l}\infty \\
0 \\
0\end{array}$ & 8 & & $\begin{array}{l}\infty \\
\infty \\
0 \\
0\end{array}$ & $\begin{array}{l}\infty \\
\infty \\
0^{\circ}\end{array}$ & $\infty$ & & $\begin{array}{l}\infty \\
\infty \\
0 \\
0 \\
\end{array}$ & $\begin{array}{l}\hat{\infty} \\
0 \\
0\end{array}$ & $\begin{array}{l}\infty \\
0 \\
0\end{array}$ & & 8 & $\begin{array}{l}\infty \\
\infty \\
0 \\
0\end{array}$ & $\begin{array}{l}\infty \\
\infty \\
0\end{array}$ & $\mid \begin{array}{l}\infty \\
\infty \\
0\end{array}$ & & 0 & 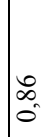 & \\
\hline 焉 & $\stackrel{\infty}{\infty} \underset{-}{-}$ & 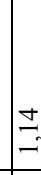 & & ஃ. & ஃ. & รั) & & ஃ. & à & $\hat{o}$ & & $b^{\circ}$ & $\hat{\hat{a}}$ & $\hat{\delta}$ & $\hat{\delta}$ & & S. & $\hat{\delta}$ & \\
\hline 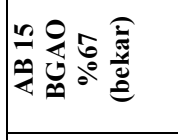 & {$\left[\begin{array}{l}\infty \\
\infty \\
0 \\
0\end{array}\right.$} & $\begin{array}{l}\bar{\infty} \\
\dot{0}\end{array}$ & & $\begin{array}{c}\tilde{N} \\
\infty \\
0 \\
0\end{array}$ & $\begin{array}{c}\infty \\
\infty \\
0 \\
0\end{array}$ & $\infty$ & & $\begin{array}{l}\infty \\
\vdots \\
0 \\
0\end{array}$ & $\hat{\hat{\theta}}$ & $\begin{array}{l}\bar{\infty} \\
0 \\
0\end{array}$ & & 8 & $\hat{2}$ & $\begin{array}{l}\infty \\
\infty \\
0\end{array}$ & $\begin{array}{l}\infty \\
0 \\
0\end{array}$ & & ". & $\mid \begin{array}{l}0 \\
\infty \\
0 \\
0\end{array}$ & \\
\hline Uิ & $\begin{array}{c}\infty \\
\infty \\
0_{0}\end{array}$ & $\mid \begin{array}{l}\infty \\
0 \\
0\end{array}$ & & $\begin{array}{c}\infty \\
\infty \\
\infty \\
0 \\
0\end{array}$ & $\begin{array}{c}\infty \\
\infty \\
0\end{array}$ & 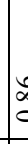 & & $\begin{array}{l}1 \\
\infty \\
\vdots \\
0 \\
0\end{array}$ & $\mid \begin{array}{l}n \\
\infty \\
0 \\
0\end{array}$ & $\begin{array}{l}\circ \\
\infty \\
0\end{array}$ & & 8 & $\mid \begin{array}{l}n \\
\infty \\
0 \\
0\end{array}$ & $\begin{array}{l}\infty \\
\infty \\
0 \\
0\end{array}$ & $\begin{array}{l}+ \\
\infty \\
0^{+}\end{array}$ & & 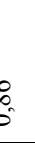 & $\mid \begin{array}{l}\infty \\
0 \\
0\end{array}$ & \\
\hline 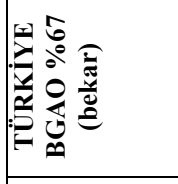 & $\stackrel{\text { }}{\overbrace{}}$ & స్తి & & ¿े & do & 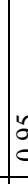 & & os & 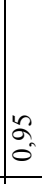 & 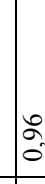 & & : & $\stackrel{2}{2}$ & 8 & $\begin{array}{l}0 \\
\infty \\
0^{\circ}\end{array}$ & & 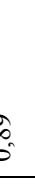 & $\mid \begin{array}{l}\hat{0} \\
0_{0}^{\circ}\end{array}$ & \\
\hline$\frac{\bar{\pi}}{\bar{\Xi}}$ & 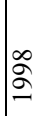 & よ & & 商 & $\underset{\sim}{\stackrel{\sim}{~}}$ & 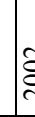 & & ఫ్ & 离 & ¿े & & 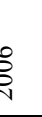 & ¿ે & 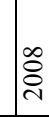 & ¿े & & ते & $\overrightarrow{\stackrel{\vec{N}}{2}}$ & \\
\hline
\end{tabular}


vergisi yapı itibari ile 1980 yılında 7 vergi diliminden oluşmuş ve vergide en düşük oran $\% 40$ iken en yüksek oran \%66 olarak belirlenmiștir. Dilim sayısı ve oranlarda yıllar itibari ile değişimler öngörülmüștür. Bu bağlamda 1992 yllında 6 olan gelir vergisi dilim sayısı 1994-1997 döneminde yeniden arttırllarak 7’ye yükseltilmiştir. 1999 yılında ise gelir vergisi dilim sayıs1 6'ya indirilmiş ve yüksek oran $\% 45$ olarak belirlenmiştir. Dilim sayısındaki azalma 2005 ve 2006 yıllarında da devam ederek 4 dilime kadar inmiş ve 4 vergi dilimi üzerinden, gelir vergisi oranları $\% 15$, $\% 20, \% 27, \% 35$ olarak tespit edilmiştir(http://www. gib.gov.tr/index.php?id=1367/20/01/2014). Ayrica 2006 yılında getirilen bir diğer düzenleme ile bu döneme kadar ücret dışı gelir elde edenlere uygulanan ve üst gelir diliminde ücret geliri elde edenlere göre $\% 5$ 'lik artışa neden olan uygulama bu dönem itibari ile son bulmuştur. Bu noktada Tanzi ve Zee'nin 2000 yılındaki çalışmalarında da belirttiği gibi özellikle gelişmekte olan ülkelerde etkin artan oranlılık uygulaması vergi dilimi sayısının arttırılması ile sağlanmaya çalışıldığından, söz konusu dönemlerde vergi dilim sayısındaki düşüşe rağmen artan oranlılık katsayılarında olumsuz bir gelişme gözlenmemiş hatta gelişmeler olumlu yönde olmuştur. Söz konusu gelişmelerin nedenleri arasında, sistemin vergi dilim sayılarındaki artışla sınırlı kalan görünürde bir artan oranlılık özelliğine sahip olması gelebilir. Bu değişimler dışında 2008 yllından itibaren vergi sisteminin yükselen artan oranlllı özelliğinin gerisinde 01/01/2008 tarihinde yeniden düzenlenen ve uygulamaya konulan asgari geçim indirimi uygulamasıda yer almaktadır. Asgari geçim indirimi uygulaması vergi sisteminde sosyal adalete uygun olarak bir artan oranlılı özelliği kazandırabilmektedir (Karayılmazlar ve Güran, 2005, s. 159).Ele alınan dönem içinde artan oranlılık konusunda olumlu etki yaratan bir diğer uygulama ise 01/03/2009 tarihinde işverenler üzerindeki mali yükümlülügün hafifletilmesini hedefleyen 5838 sayılı Kanunun yürürlüğe girmesidir. Tüm bu uygulamalar kapsamında artan oranlılık endeksi tüm gelir grupları için düşüş yönlü bir seyir izleyerek sistemin artan oranlılık özelliği yükselmiştir. Tüm bu olumlu yükselmeye rağmen söz konusu dönemde Türkiye'de ücret vergilerinin artan oranlılık özelliği OECD ve $\mathrm{AB} 15$ ülke ortalamalarının gerisinde kalmaktadır. Özellikle bu karşılaştırmalar da göze çarpan farklılık OECD ve $A B 15$ ülkelerinde, ortalama gelirin yüzdesi olarak gelir arttıkça artan oranlılık yükselmekte iken, Türkiye'de en düşük gelir grubu ile en yüksek grubu arasında 2011 yılı itibari ile fark bulunmamasıdır.
Ayrıca aile odaklı olarak, sosyal statüler bazında bir karşılaştırmaya gidildiğinde $\mathrm{OECD}$ ve $\mathrm{AB} 15$ ülkelerinde bekar ve iki çocuklu çalışanlar için verginin artan oranlılık özelliği yükselmekte iken Türkiyede gerek sosyal statü gerekse gelir düzeyi noktasında artan oranlılık katsayılarında önemli bir değişiklik olmamaktadır.

Türkiye'de aile odaklı olarak değişen ücret yapısındaki gelir grupları incelendiğinde ise artan oranlılık katsayıları Tablo 2'deki gibi gerçekleşmiştir. Eşlerden birinin çalıştığı iki çocuklu ailelerde, vergi sistemini artan oranlılığ 2000 yılı itibari ile artama eğilimi gösterse de, OECD ve $A B 15$ ülke ortalamasını oldukça gerisinde kalmaktadır. Ayrıca OECD ve AB 15 ülke ortalamasında tek çalışanlı, 2 çocuklu ailelerde vergi sisteminin artan oranlıllk özelliği, diğer ekonomik ve sosyal statüye sahip ailelere göre daha yüksek iken bu ayrım Türkiye'de gözlenememiştir. Eşlerin her ikisinin de çalıştığı ve ortalama ücretin belli bir oranını kazandığı gruplar arasında ise vergi sisteminin artan oranlılığ 1 çok az değişmekte ve OECD ve AB 15 ülke ortalamalarının çok gerisinde kalmaktadır. Bu durum aile odaklı ekonomik ve sosyal politika hedefleri ile vergi sisteminin çok da paralel şekillenmediğinin bir göstergesi olabilmektedir. Türkiye'den farklı olarak OECD ve $A B 15$ ülkelerinde sosyal statü olarak evli, eşlerden birinin çalıştığı ve çocuklu olan gelir grupları,bekar ve çocuksuz gruplara göre yüksek artan oranlılığa sahip bir sisteme tabiidir. Böylece sistem sosyal adalet açısından evli ve çocuklu grupları desteklemektedir.

Türkiye için ise hedef, gelir dağılımının yoksul gruplar lehine yeniden dağılımı ve 9. Plan çerçevesinde yoksul ailelere yönelik gelir artışı sağlanması gibi aile odakl, sosyal ve ekonomik politikaların geliştirilmesi olduğunda artan oranlılık katsayılarımız hedeflerle uyumlu ve/veya yeterli bir gelişim göstermemektedir.

Tablolar yardımı ile de görüldügü üzere ücret vergileri sistem olarak yıllar içinde yükselen artan oranlık özelliğine rağmen özellikle alt gelir grupları ve farklı sosyal statülerin çıkarları doğrultusunda OECD ve $\mathrm{AB} 15$ ülkelerine göre oldukça düşük artan oranllık özelliği taşımaktadır. Bu noktada vergi sisteminin artan oranlılık endeksleri ile ölçülüp katsayının l'den küçük çıkması durumunda vergi sisteminin artan oranlı olarak nitelendirilmesi esas itibari ile sistemin sosyal adalet açısından arzu edilir yada ülke hedefleri uyumlu olduğunun göstergesi olmamaktadır. Düşük 


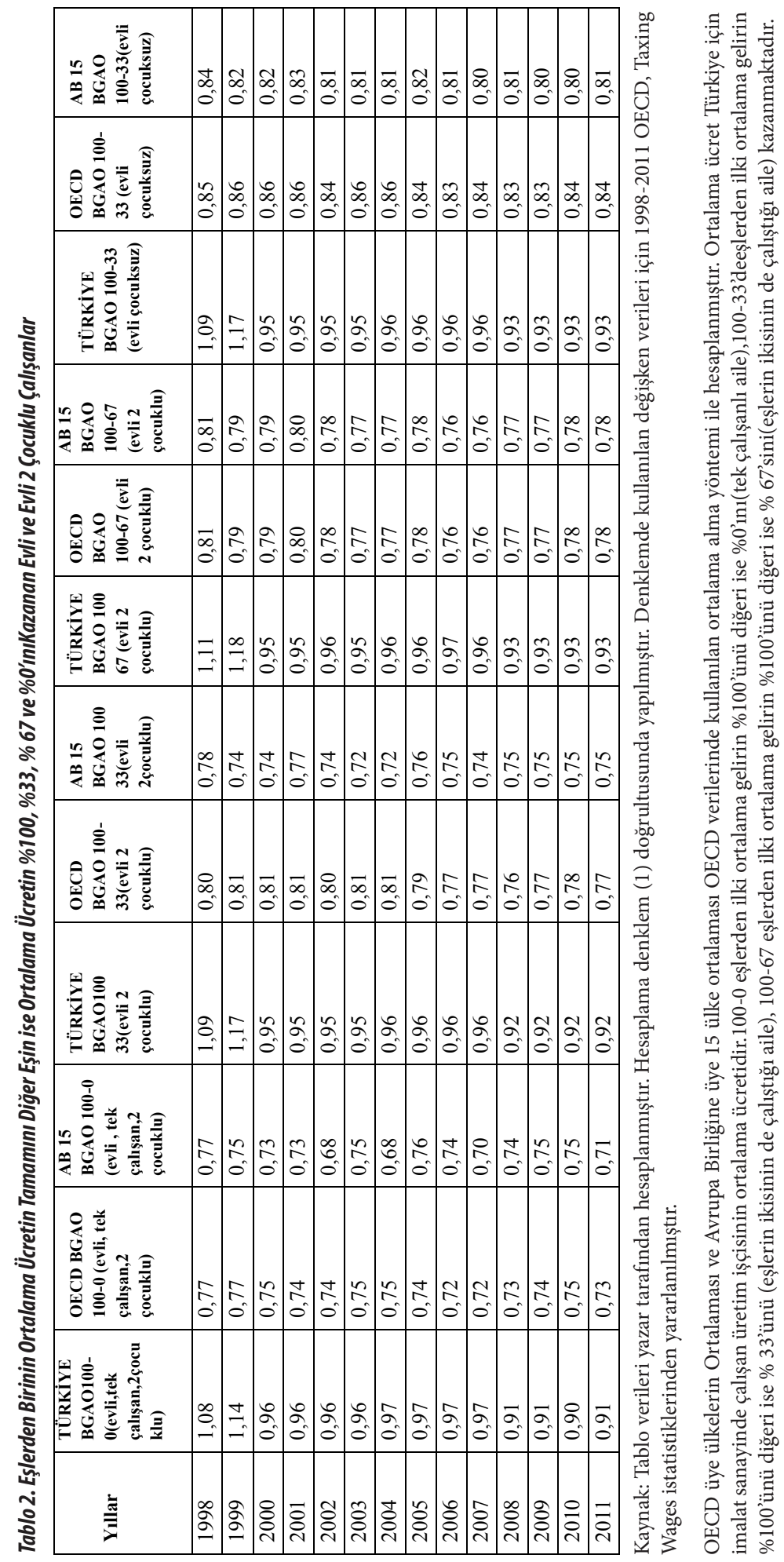


artan oranlılık özelliği bir taraftan gelir dağılımı hedeflerinin sosyal adalet amacından uzaklaşmasına neden olurken diğer taraftan, uygulanan vergi ve yükümlülükler vergi öncesi ve sonrası gelir arasında farkı diğer bir ifade ile vergi takozunu(kamasını) arttırarak daha öncede değinildiği üzere istihdam ve kayıt dışı ekonomi hedeflerini olumsuz etkileyebilmektedir. Bu nedenle düşük artan oranlılık özelliğinin neden olabileceği hedeflerle uyumsuzluk yanında, özelikle sosyal adalet ve istihdam politikaları ile vergi sisteminin uyumu açısından vergi kamasının ve OECD tarafından kullanılan vergi kaması artan oranlılığının ölçülmesi önemli bir diğer nokta olmaktadır.

Vergi kaması (tax wedge) OECD tarafından; bir işçinin işverene brüt maliyeti ile işçinin eline geçen net ücret(sigorta primi ve gelir vergisi kesintileri yapıldıktan sonra) arasındaki farkın brüt ücrete oranı ola- rak tanımlanmaktadır (OECD, 2011). Tanımı yapılan vergi kamasının Türkiye için yıllar itibari ile gelişimi ise Tablo 3' de gösterilmektedir.

Tablo 3' de görüldüğgü üzere vergi kaması hem ortalama ücret düzeyinde gelir elde eden bekar hem de yine ortalama ücret düzeyinde gelir elde eden tek çalışanlı, iki çocuklu aileler için genelde düşüş yönlü bir seyir izlemiş, fakat düşüşözellikle 2008 yılından sonra daha belirgin bir hal almış, ayrıca sosyal statüler arasındaki farklılaşma doğrultusunda evli ve iki çocuklu aile ile bekar çalışanlar arasındaki vergi kaması oranları değişmiştir. Bunun temelinde ise özellikle yıllar itibari ile düşen enflasyon oranları ve vergi sistemindeki değişmeler yer almaktadır. 2011 yılında vergi kaması OECD ülke ortalaması için \%35,2 olarak belirlenirken, Türkiye'de bu oran \%37,7 olarak gerçekleşmiştir. Bu noktada OECD ve AB 15 ülkeleri ile Türkiye ara-

Tablo 3.Türkiye'de İstihdam Maliyetinin Yüzdesi Olarak Vergi Kaması (Takozu) Oranları

\begin{tabular}{|c|c|c|}
\hline Yıllar & $\begin{array}{c}\text { Ortalama Ücret Düzeyinde Gelir } \\
\text { Elde Eden Çalışanlar (Bekar) } \\
\text { Üzerindeki Toplam Vergi } \\
\text { Kaması(İstihdam Maliyetinin } \\
\text { Yüzdesi Olarak) }\end{array}$ & $\begin{array}{c}\text { Ortalama Ücret Düzeyinde Gelir } \\
\text { Elde Eden Tek Çalışanlı 2 } \\
\text { Çocuklu Aileler Üzerindeki } \\
\text { Toplam Vergi Kaması(İstihdam } \\
\text { Maliyetinin Yüzdesi Olarak) }\end{array}$ \\
\hline 1998 & 40,3 & 40,3 \\
\hline 1999 & 40,3 & 40,3 \\
\hline 2000 & 40,4 & 40,1 \\
\hline 2001 & 43,6 & 43,6 \\
\hline 2002 & 42,4 & 42,4 \\
\hline 2003 & 42,1 & 42,1 \\
\hline 2004 & 42,7 & 42,7 \\
\hline 2005 & 42,7 & 42,7 \\
\hline 2006 & 42,8 & 42,8 \\
\hline 2007 & 42,7 & 42,7 \\
\hline 2008 & 39,7 & 38,5 \\
\hline 2009 & 37,5 & 36,2 \\
\hline 2010 & 37,4 & 37,0 \\
\hline
\end{tabular}

Kaynak: OECD, Taxing Wages,1998-2011

sındaki bir diğer önemli fark, çocuklu aileler ile bekar çalışanlar arasındaki vergi kaması farkının oldukça düşük olmasıdır. OECD ülkelerinin bir çoğunda evli ve çocuklu aileler vergi avantajı gibi düzenlemelerle korunurken Türkiye'de ise iki gelir grubu arasındaki fark \%1 düzeyinde kalmaktadır.

$\mathrm{Bu}$ sonuçlar ışığında çalışmamızın ilk tespiti, elde edilen ücret vergilerindeki düşük artan oranlllık düzeyi yanında Tablo 3'de belirtilen yüksek vergi kaması oranlarıdır. Sosyal güvenlik primleri ve vergiler ne- deni ile bireylerin vergi öncesi ve vergi sonrası geliri arasındaki farkın giderek açılmasına neden olan vergi kaması kayıtlı sektördeki istihdam kararları üzerinde bozucu etki yaratarak kayıtdışı ekonominin temel nedenlerinden biri halini almaktadır (Buehn ve Schnedier, 2012, s. 5). Dünya bankasının, merkezi Asya ve geçiş ekonomilerini kapsayan 2000 yılındaki çalışması da vergi kaması istihdam ve kayıtdışı ekonomi arasındaki doğrusal ve pozitif yönlü ilişkinin varlığını doğrulamaktadır (World Bank, 2000). Genel istihdam üzerindeki bu olumsuz etkilerinin 
yanı sıra ücretler üzerindeki vergilerdeki bir yükselmenin (dolayısı ile vergi kamasındaki artışın), işgücü talebinin yüksek olduğu çalışan kesimin istihdamı üzerindeki etkisinin daha yoğun olduğu bilinmektedir. Ayrıca özellikle düşük vasıflı yada vasıfsız çalışanlar olan genç, yaşlı ve kadınlardan oluşan çalışan grubunun istihdamı üzerindeki negatif etkinin, söz konusu grupların işgücü arz elastikiyeti nedeni ile daha yüksek olduğu ileri sürülmektedir (Rutowski ve Walewski, 2007, s. 295-296). Bu kapsamda Avrupa Birliği 2020 stratejisinde yüksek vergi kamasının üye ülkelerde vasıfsız işçi istihdamını olumsuz etkilediği sonucuna varılmıştır (http://ec.europa.eu/ europe2020/pdf/themes/20_tax_burden_on_labour. pdf/20/12/2013). Gora vd. 2009 yılında yapmış oldukları çalışmada da Avrupa Birliği stratejisi bulgularına paralel olarak, düşük gelir elde eden vasıfsız işçiler üzerindeki vergi kamasının düşürülmesinin istihdam üzerinde olumlu kayıtdışı ekonomi üzerinde ise azaltıcı etkisinin olduğu sonucuna varılmışlardır. $\mathrm{Bu}$ sonuçlar, Türkiye’nin 9. Beş yıllık kalkınma planı çerçevesinde belirlediği istihdam odaklı politika hedeflerine çözüm olacak bir vergi sisteminin varl1ğı noktasında soru işaretleri yaratmaktadır. Özellikle genç nüfusun yüksek olduğu ülkemizde vergi kamasının bu grubun istihdamı üzerindeki olumsuz etkisi önem arz etmektedir. Bu ilişkileri Türkiye ekonomisi içinde doğrulayan bir çalışma Betcharman ve Pages tarafından 2007 yılında yapılmıştır. Çalışmada işverenin sosyal güvenlik katkı payında yapılacak $\% 5^{\prime}$ lik bir indirimin, toplam istihdamda \%0,8'lik bir artışa ve işsizlikte $\% 0.3^{\prime}$ lük bir azalmaya neden olacağ 1 tespit edilmiştir. Katkı payındaki bu azalışın etkisi 30 yaş altı istihdam üzerinde etkisi\%1,5'lik yükseliş ile kendini göstermektedir. Sözü edilen etkilerin yanı sıra vergiler ve vergi kaması üzerindeki bir artış kayıtlı istihdam maliyetlerini kayıt dışı istihdama göre arttırmakta ve kayıtlı istihdamda kayıtdışı istihdam lehine azalma yaratabilmektedir. Böylece kayıtdışı istihdamdaki artış düşük vergi geliri anlamına geldiğinden, finansal açıdan olumsuz sonuçlar doğurabilmektedir. $\mathrm{Bu}$ olumsuzluğun yanı sıra kayıtdışındaki yükselme kayıtlı işletmelerin optimal düzeyin altında kalmasına neden olduğundan ekonomik büyümeyi de etkilemektedir (Rutowski ve Walewski, 2007, s. 295-296). Tüm bu açılamalar ışı̆̆ında genel bir ifade ile vergi kaması ne kadar büyük olursa, işgücü pazarlarına etkisi de o kadar büyük olması beklenir (OECD, 2007). Bu noktada Türkiyede vergi kamasının yüksekliği 9. Plan kapsamında yer alan kayıtdışı işletme, kişi ve çalışanların kayıt altına alınması ve hem vergi politika- ları hem de transfer politikalarıyla gelir dağılımının iyileștirilmesi ve yoksullukla mücadele hedefleri ile uyumlu bir yapı sergilememektedir.

Belirlenen sosyo-ekonomik hedeflere ulaşılması için vergi kamasının bu olumsuz etkilerinin giderilip, oransal olarak düşürülebilmesi üç faktöre bağlıdır ve bu faktörlerin doğru yönetimi vergi kamasını azaltabilir. 2007 yılı OECD istihdam görünüm raporunda vergi kamasını azaltacak bu üç faktörden ilki; uygulanan vergi karmasının yapısı olarak belirtilmiştir. Raporda gelir vergisi ve tüketim vergileri gibi genel vergilendirme türlerinin kullanılmasının vergi kamasını düşürdüğü görüşü yer almaktadır. İkinci faktör ise ödenen vergiler ile alınan sosyal yardımlar arasında daha güçlü bir bağ yaratılmasının vergi kamasının etkisini azaltmaya yardımcı olabileceğidir. Son faktör ise vergilerin artan oranlı olmasıdır. Özellikle asgari ücretin yüksek olduğu durumlarda vergi kaması düşük ücretli işlerde özellikle büyük bir etki yapabileceğinden vergi kamasının istidam üzerindeki etkisinin azaltılmasında, OECD tarafindan daha artan oranlı finansman kaynaklarının tercih edilmesini önerilmektedir. Fakat üzerinde vergi kamasının olumsuz etkisinin yoğun olarak görüldüğü düşük ücret düzeylerinde, işsizlikle mücadele için özellikle işveren üzerindeki mali yüklerin azaltılarak düşük gelir grupları üzerindeki vergi kamasının düşürülmesi politikalarının desteklenmesi, korunmasız gruplar arasında istihdamın arttırılmasında etkin bir yol olmayacağından, düşük gelir grupları üzerindeki vergi kamasının azaltılmasında, optimal bir artan oranlılık düzeyi göz önünde bulundurularak artan oranlılık özelliğinin vergi sisteminin tamamına kapsayacak şekilde artt1rılması önerilmektedir. Bu noktada vergi sisteminin artan oranlılığının ölçülmesinde OECD vergi kaması artan oranlılık yaklaşımının kullanılması tavsiye edilmektedir (OECD, 2007, s. 158-160).Bu tavsiye doğrultusunda Türkiye için vergi kaması artan oranlllı̆̆ının ölçülmesi ve bu doğrultuda politikaların üretilmesi açısından önem taşımaktadır.

Tablo 4'de elde edilen sonuçlar doğrultusunda vergi kaması artan oranlılık ölçümleri ile düşük gelir grupları üzerindeki vergi kamasının yüksek gruplara oranla ne düzeyde olduğunun tespiti ve bu doğrultuda vergi kamasının işsizlik, gelir dağılımı ve kayıt dışı ekonomi üzerindeki etkileri konusunda daha net sonuçlara ulaşılabilmektedir. Türkiye için vergi kamasının artan oranlılığ yıllar itibari ile artmış özellikle 2008 yılında getirilen ve daha öncede deği- 
Tablo 4. Türkiye OECD ve AB15 Ülkeleri Vergi Kaması Artan Oranlıık Ölçümleri

\begin{tabular}{|c|c|c|c|c|c|c|}
\hline Yillar & $\begin{array}{l}\text { Türkiye' de } \\
\text { Vergi Kaması } \\
\text { Artan } \\
\text { Oranlılığı } \\
\text { (bekar) }\end{array}$ & $\begin{array}{l}\text { OECD Vergi } \\
\text { Kaması Artan } \\
\text { Oranlılığı } \\
\text { (bekar) }\end{array}$ & $\begin{array}{l}\text { AB } 15 \text { Vergi } \\
\text { Kaması Artan } \\
\text { Oranlılı̆̆ı } \\
\text { (bekar) }\end{array}$ & $\begin{array}{l}\text { Türkiye'de } \\
\text { Vergi } \\
\text { Kaması } \\
\text { Artan } \\
\text { Oranlılığı } \\
\text { (evli) }\end{array}$ & $\begin{array}{l}\text { OECD } \\
\text { Vergi } \\
\text { Kaması } \\
\text { Artan } \\
\text { Oranlılığı } \\
\text { (evli) }\end{array}$ & $\begin{array}{l}\text { AB15 Vergi } \\
\text { Kaması } \\
\text { Artan } \\
\text { Oranlılığı } \\
\text { (evli) }\end{array}$ \\
\hline 1998 & $-0,15$ & 0,19 & 0,18 & 0,04 & 0,13 & 0,09 \\
\hline 1999 & $-0,27$ & 0,20 & 0,19 & 0,08 & 0,16 & 0,12 \\
\hline 2000 & $-0,12$ & 0,18 & 0,20 & $-0,01$ & 0,16 & 0,12 \\
\hline 2001 & 0,06 & 0,21 & 0,20 & $-0,01$ & 0,15 & 0,13 \\
\hline 2002 & 0,07 & 0,20 & 0,20 & $-0,01$ & 0,16 & 0,15 \\
\hline 2003 & 0,08 & 0,22 & 0,22 & $-0,01$ & 0,14 & 0,13 \\
\hline 2004 & 0,06 & 0,22 & 0,23 & $-0,01$ & 0,14 & 0,14 \\
\hline 2005 & 0,06 & 0,20 & 0,20 & $-0,01$ & 0,15 & 0,12 \\
\hline 2006 & 0,06 & 0,20 & 0,20 & $-0,01$ & 0,15 & 0,12 \\
\hline 2007 & 0,06 & 0,21 & 0,20 & $-0,01$ & 0,16 & 0,13 \\
\hline 2008 & 0,12 & 0,20 & 0,20 & 0,04 & 0,15 & 0,12 \\
\hline 2009 & 0,13 & 0,21 & 0,20 & 0,04 & 0,17 & 0,12 \\
\hline 2010 & 0,13 & 0,21 & 0,20 & 0,05 & 0,16 & 0,12 \\
\hline 2011 & 0,13 & 0,20 & 0,19 & 0,04 & 0,17 & 0,16 \\
\hline
\end{tabular}

Kaynak: OECD, Taxing Wages,1998-2011 verileri doğrultusunda denklem (2)'e göre Türkiye, OECD üye ülkelerin Ortalaması ve Avrupa Birliğine üye 15 (AB 15) ülke ortalaması için tarafımızdan hesaplanmıştır. OECD üye ülkelerin Ortalaması ve Avrupa Birliğine üye 15 ülke ortalaması OECD verilerinde kullanılan ortalama alma yöntemi ile hesaplanmıștır.

nilen düzenlemeler paralelinde, 2011 yılında \%13’e kadar yükselmiştir. Vergi kaması artan oranlılığının bu düzeye varması alt gelir grupları üzerindeki vergi kamasının, üst gelir gruplarına göre \%13 daha düşük olduğunu göstermektedir. 1998 ve 1999 yıllarında vergi kamasının üst gelir grupları lehine düşük olduguundan hareketle, gelişmeler olumlu olarak karşılansa da vergi kaması artan oranlılı̆̆ 1 istihdam ve gelir dağılımı üzerindeki etkileri göz önüne alındığında halen $\mathrm{OECD}$ ve $\mathrm{AB} 15$ ülke ortalamalarının gerisinde kalmaktadır. Evli ve 2 çocuklu aileler dikkate alındığında ise durum tamamen farklılaşmaktadır. Alt gelir gruplarının vergi kaması artan oranlılığı, üst gelir gruplarına göre \%0,4 gibi çok çok düşük bir oranda gerçekleşmekte, diğer bir ifade ile alt gelir grupları üzerindeki vergi kamasının, üst gelir gruplarına göre sadece $\% 0,4$ daha düşük olarak gerçekleşmektedir. Alt gelir grubunda yer alan iki çocuklu ve evli aileler için vergi kaması artan oranlılığının bu kadar düşük olması bu gruplar aleyhine gelirin dağıldığının bir göstergesi olarak yorumlanabilir.

Ele alınan dönemler arasında, vergi kamasının ar$\tan$ oranlılığ 1 değişim gösterse de istenilen düzeye ulaşamamasının gerisindeki yapısal nedenlerin incelenmesi önem taşır. Birçok ülkede vergi kamasının artan oranlılığ 1 , bireysel gelir vergisinin artan oranlı yapısı ile açıklanır, çünkü vergi kamasını oluşturan gelir vergisi ve sosyal güvenlik katkı payı yada sosyal yardımlardır. Regresif yapısı olan sosyal güvenlik katkı payının kama içindeki oranının yükselmesi ise beraberinde vergi kaması artan oranlılığının düşmesini getirmektedir (OECD, 2007, s. 172). Bu noktada Türkiye’nin mevcut yapısı incelendiğinde 2011 yılı itibari ile istihdam maliyetinin \%37,7'si olan vergi kaması; \%10,7 oranında gelir vergisi ve \% 27 oranında sosyal güvenlik katkı payından oluşmaktadır. Ülkemizde istihdam üzerindeki vergi makası, kayıt dışılığ teşvik eden bir yapıdadır. Bu yapının değiştirilmesi için istihdam üzerindeki vergi ve sosyal güvenlik yükünün azaltılması gerekmektedir. Vergi makasının büyüklüğü gelir vergisi oranının yüksekliğinden daha çok sosyal güvenlik katkı paylarının yüksekliğinden kaynaklanmaktadır(GİB,2008, s. 27).Sosyal güvenlik katkı payının vergi kaması içindeki bu yüksek oranı ve söz konusu katı payının genellikle düz oranlı ve regresif yapısından kaynaklanır. Katkı payının istihdam üzerindeki olumsuz etkilerinin giderilmesi, 
kayıtdışı istihdamın azaltılması ve eşitlikçi bir gelir dağılımı hedeflerine ulaşmasında, tercih edilebilecek seçeneklerin başında vergi kaması içinde baskın olan sosyal güvenlik payının düşürülmesi gelmektedir (OECD, 2007, s. 172).Sosyal güvenlik katkı payının düşürülmesinde üç temel yoldan bahsedilebilir. Bunlardan ilki gelir tahsilatının güçlendirilip, kayıt dışılı$\breve{g}$ ın engellenmesi ile sosyal güvenlik sisteminin etkinliğinin arttırılmasıdır. İkinci yol ise sosyal güvenlik sisteminin sigorta tabanlı kısmının sinırlandırılması ve vergi ile finansman payının arttırılmasıdır. Üçüncü yol,sosyal sigorta primlerinin özellikle işgücü talep esnekliğinin göreceli olarak yüksek ve geçişkenlik etkisinin düşük olduğu çalışan grupları lehine düşürülmesidir. Bu indirim işsizliğin en çok etkilediği düşük vasıflı ve genç çalışanların işveren üzerindeki maliyetlerini düşürerek istihdam şanslarını arttıracak (Rutowski, Waleski, 2007, s. 301-302) diğer taraftan sosyal güvenlik primlerinin vergi kaması içinde düşen payı, kamanın artan oranlılık özelliğinin yükselterek, gelir dağılımına olumlu katkı sağlayabilecektir. Bu noktada daha önce Belçika, Hollanda ve Fransa'da uygulanmış olan düşük gelir grupları lehine sosyal güvenlik katkı payındaki indirimler ve artan oranlı gelir vergisi lehine düzenlemeler, Türkiye'de,özellikle gerek vergi sisteminin düşük artan oranlılığ 1 , gerekse yüksek vergi kaması ve düşük vergi kaması artan oranlılığı nedeni ile istihdam ve gelir dağılımı açısından olumsuz etkilenen alt gelir gruplarında yer alan ve düşük vasıflı çalışanların istihdamı lehine sonuçlar doğurabilecektir. Ayrıca kayıtlı sektördeki işsizlik kayıt dıșı istihdamın temel nedenlerinin başında gelmektedir (Dobre ve Alexandru, 2009, s. 187). Türkiye özeli alındığında ise Ankara Ticaret Odası kayıt dışı istihdam raporunda kayıtlı istihdamın kayıtdışı lehine büyüdügü görülmektedir (http://www.atonet. org.tr/22/12/2013). Bu raporu destekler nitelikte bir diğer çalışma ise Betcherman ve Pages 2007 yllındaki çalışmalarıdır. Söz konusu çalışmada belirtildiği gibi Türkiye'de kayıtlı sektörlerde yaratılacak ek istihdam kayıtdışı sektörün kayıtlı hale gelmesi ile sağlandığından, vergi kamasının düşürülmesi yolunda atılacak adımlar Türkiye’nin kalkınma planlarındaki bir diğer hedefi olan kayıtdışı ekonomi ile mücadele hedefine de hizmet edecektir. Ayrıca söz konusu indirimler, Türkiye özelinde bekar, bekar çocuklu, evli tek eşin çalıştığ 1 ve çocuklu, evli eşlerin ikisinin de çalıştığ ve çocuklu aile ve sosyal statüler göz önüne alınarak uygulandığında, OECD ve $A B 15$ ülkelerinde olduğu gibi sosyal adalet açısından ülkelerin sosyal politikaları çerçevesinde hedef grupları destekleyebildi- ği bir yapıya kavuşturulabilecektir. Sosyal güvenlik primlerinin azaltılması ve gelir vergisi finansman payının arttırılması özellikle etkinlik açısından vergi tahsilatının da güçlendirilmesini gerekli kıldığından Türkiye'nin vergi tahsilatında attığı olumlu adımları hızlandırmasını gerekli kılacaktır.

\section{Sonuç}

Türkiye’nin sosyo-ekonomik olarak temel hedeflerinin başında kayıtlı sistemin güçlendirilmesi, işsizliğin azaltılması ve işgücü piyasasının etkinleştirilmesinin sağlanması, yoksulluk ve gelir dağılımındaki dengesizliklerin kalıcı bir şekilde azaltılması gelmektedir. $\mathrm{Bu}$ paralelde ulaşılmak istenen hedefler doğrultusunda uygulanan farklı mali politika araçlarından biride ücret vergileridir ve ücret vergilerinin yapısı sosyo ekonomik hedeflerle uyumlu olduğu sürece hedefler ulaşılabilir olmaktadır. Bu nedenle ücret vergilerinin gelir grupları bazında sahip olduğu artan oranlılık özelliği ekonomik hedeflerin gerçekleşmesi açısından önem arz eder. Fakat mevcut yapısı ile ücret vergileri Türkiye'nin ekonomik hedeflerine uygun görünmemektedir. Ücretler üzerindeki mali yükümlülükler artan oranlılık endeksleri ile test edildiğinde vergi sistemi düşük de olsa artan oranlı gibi görülse de, vergi kaması OECD ve AB 15 ülke ortalamasını üzerinde kalmakta ve vergi kaması artan oranlılık endeksi söz konusu ülke ortalamalarının çok gerisinde seyretmektedir. $\mathrm{Bu}$ doğrultuda vergi sisteminin herhangi bir endekse göre artan oranlı olarak bulunması, gelirin adil ve hedefler doğrultusunda dağıldığı anlamina gelmemektedir. Türkiye örneğinde olduğu gibi artan oranlılık endeksi birçok farklı çalışmada vergi sisteminin tümü için 1'den küçük olmakla birlikte gelir grupları arasındaki artan oranlılık ve vergi kaması farklılıkları göz önüne alındığında sistem gelir dağılımında adalet hedefi ile uygun olmayabilmektedir.

Ayrıca artan oranlılık katsayıları genel itibari ile artış gösterse de sosyal statüler göz önüne alındığında OECD ve $A B 15$ ülkelerinin tersine,vergi sistemi yoksul ailelere yönelik gelir artışı sağlanması gibi aile odakl, sosyal ve ekonomik politikalara uyumlu ve/ veya yeterli bir gelişim göstermemektedir. Sosyal politikalarla aile ve çocuk desteklense de mevcut ücret vergi sistemi bekar ve çocuksuz çalışanlar lehine düzenlenmiş görünmektedir. Ücret vergilerinin sahip olduğu düşük artan oranlılık özelliği gelir dağılımı hedeflerini olumsuz etkilerken, uygulanan vergi ve yükümlülükler vergi takozunu (kamasını) arttıra- 
rak istihdam ve kayıt dışı ekonomi hedeflerinden uzaklaşılmasına neden olmaktadır. Ayrıca vergi kamasındaki artışın özellikle düşük vasıflı yada vasıfsız çalışanlar olan genç, yaşlı ve kadınlardan oluşan çalışan grubunun istihdamı üzerindeki negatif etkisinin yüksek olduğu göz önüne alındığında, genç nüfusun yoğun olduğu ülkemiz için vergi kamasının istihdam üzerindeki olumsuz etkisi ayrıca önem arz etmektedir. Vergi kamasının bu olumsuz etkilerinin giderilmesi ve oransal olarak düşürülebilmesi ise başta vergi sisteminin artan oranlılığının arttırılması ile mümkün olabilmektedir. Bu açıdan bakıldığında ekonomik ve sosyal hedeflere ulaşılması, vergi kaması ve artan oranlılığın karşılıklı etkileşimi ile mümkün olabilmektedir. Bu nedenle, hedeflere uygun olarak ücretler üzerindeki vergi kamasının, düşük gelir grupları lehine azaltılması ayrıca kama içinde gelir vergisinin payının yükseltilerek sistemin daha artan oranlı hale getirilmesi, bir taraftan işsizlikle mücadelede düşük gelir ve vasıf gruplarına hizmet edecek, diğer taraftan gelir dağıllıminda bu gruplar lehine düzelmeler sağlayabilecek ayrıca kayıtdışı ile mücadeleyi kolaylaştıracaktır.

Sonuçta ekonomik ve sosyal hedefler ancak doğru araçlar kullanıldığında ulaşılabilirdir. Bu noktada hedeflerimize ulaşmamız için olumlu adımlar atılmış olması önemli bir gelişmedir. Bu adımlar ücret vergi sistemin tamamen yeniden dizaynı yerine önemli değişliklerle hedeflerle uyumlu hale gelmesine hizmet edecektir.

\section{Kaynakça}

Aggarwal, P.K. (1994). A Local Distributional Measure of Tax Progressivity. Public Finance, 49(1),1-11.

Alesina, A. ve.Perotti, R.(1997).The Welfare State and Competitiveness. The American Economic Review, 87(5), 921-39.

Arikan, Z. ve .Bahçe, A.B.(2011).OECD ve AB Üyesi Ülkelerde Vergi Sisteminin Stratejik Tasarımı: Karşılaştırmalı Ülke Analizi. İstanbul Üniversitesi İktisat Fakültesi Mecmuası, 61(1), 27-80.

Baum, S. R. (1987). On The Measurement of Tax Progressivity: Relative Share Adjustment. Public Finance Quarterly, 15(2), 166-187.
Betcherman, G.ve Pages, C. (2007). Estimating the Impact of Labor Taxes on Employment and the Balances of Social Insurance Funds in Turkey. Synthesis Report, August 2007, World Bank.

Blackbory, C. ve Donaldson, D.(1984). Ethical Social Index Numbers and the Measurement of Effective Tax/Benefit Progressivity. Canadian Journal of Economics, 17, 683-694.

Boeter, S. (2009). Optimal Tax Progressivity in Unionized Labour Markets; What Are the Driving Forces?.CPB Discussion Paper, No:129, CPB Netherlands Bureau for Economic Policy Analysis.

Brunello, G. ve Sonneda, D. (2007). Progressive Taxation and Wage Setting When Unions Strategically Interact. Oxford Economic Paper, 59, 127-140.

Buehn, A. ve Schneider, F.(2012). Shadow Economies in High Developed Countries:What Are the Driving Forces?. IZA DP. NO:6891, October 2012,

Daveri, F. ve Tabellini, G. (2000). Unemployment, Growth and Taxation In Industrial Countries. Economic Policy, 15 (30), 47-88.

Dobre, I. ve Alexandru, A.A.(2009).The Impact of Unemployment Rate on the Dimension of Shadow Economy in Spain: A Structural Equation Approach. European Research Studies, Volume XII, Issue (4), 181-196.

Duclos, J. Y. veT abi, M. (1996).The Measurement of Progressivity. with an Application to Canada, The Canadian Journal of Economics, 29,165-170.

GİB.(2008).Kayıt Dışı Ekonomiyle Mücadele Stratejisi Eylem Planı (2008-2010). Gelir İdaresi Başkanlığ 1 SGB.Yayın No:87, Ankara.

Gora, M., A. Radiwill, A. Sowa, M. Walewski. (2006). Tax Wedge and Skills: Case of Poland in International Perspective. Center for Social and Economic Research Case Report, No:64/2006.

Gora, M., O. Rohozynsky, I. Sinitsina, M. Walewski. (2009).Social Security Driven Tax Wedge and Its Effects on Employment and Shadow Employment. Center for Social and Economic Research Case Report, No: 398/2009. 
Jacobssen, U. (1976). On The Measurement of The Degree of Progression. Journal of Public Economics, 5, 161-168

Kakwani, N. C. (1977). Measurement of Tax Progressivity: An International Comparison. Economic Journal, 87 (345), 71-80.

Karayilmazlar, E. ve Güran, M. C. (2005).Gelir Vergisinde Tarife Yapısı; Adalet ve Etkinlik Temelli Teorik Tartışmaları Çerçevesinde Karşılaştırmalı Bir Analiz. Ankara Üniversitesi Siyasal Bilgiler Fakültesi Dergisi, 60(2), 142-169.

Khetan, C. ve Poddar, S. (1976).Measurement of Income Tax Progression in A Growing Economy: A Canadian Experience. Canadian Journal of Economics, 4, 613-629.

Kosi,T. ve Bojnec, S. (2009). Level and Progressivity of Labour Income Taxation in Slovenia and Croatia.http://oliver.efri.hr/ euconf/2009/docs/session $12 / 1 \% 20$ Kosi\%20Bojnec.pdf

Lim, B. ve Hyun, J.(2004).Comparative Analysis of The Effective Income Tax Function: Empirical Evidence Using Lis Data. Luxemburg Income Study Working Paper Series, No: 369.

Musgrave, R. A., ve Thin, T.(1948). Income Tax Progression, 1929-48. Journal of Political Economy, 56 (6), 498-514.

Nickell, S. ve Layard, R.(1999). Labour Market Institutions and Economic Performance. Ed: O. Ashenfelter, D. Card, Handbook of Labor Economics, 3, North Holland, Amsterdam, 3029-84.

OECD. (2007). Employment Outlook. OECD Publishing

OECD. (2007a). Economic Survey. OECD Publishing.

OECD. (2011).Taxing Wages 1998-2011. OECD Publishing.

Paturot, D., K. Mellbye, B. Brys. (2013). Average Personal Income Tax Rate and Tax Wedge Progression in OECD Countries. OECD Taxation Papers, No: 15.
Pechman, J.A. ve Okner, B. A.(1974). Who Bears the Tax Burden?. Washington: The Brooking Institution.

Reynolds, M. ve Smolensky, E.(1977).Post Fiscal Distributions of Income In 1950, 1961, and 1970 . Public Finance Quarterly, 5, 419-38.

Rutowski, J. ve Walewski. M.(2007). Fiscal Policy and Economic Growth: Lessons For Eastern Europe and Central Asia. Ed: Cherly Grey, Tracey Lane, Aristomen E Varoudaki, The World Bank, Washington D.C.

Selim, R. ve Senesen, Ü. (1999). Gelir Vergisinin 1960'dan Sonra Türkiye Kişisel Gelir Dağılımı Üzerine Etkisi. İktisat, İşletme ve Finans Dergisi, 14 (158), 30-38.

Sorensen, P. B., V. Christiansen ve J. Dolado. (1997). Public Finance Solutions to the European Unemployment Problem?. Economic Policy, 12(25), 221264.

Suits, D.B. (1977). Measurement Of Tax Progressivity. American Economic Review, 67, 747-752.

Tanzi,V. ve Zee, H. (2000). Tax Policy For Emerging Market: Developing Countries. IMF Working Paper, WP/00/35.

Ünlükaplan, İ. (2011). Türk Vergi Sisteminin Artan Oranlılığının Ölçülmesi: 1924-2008 Dönemine Yönelik Uygulamalı Bir Analiz. Çukurova Üniversitesi Sosyal Bilimler Enstitüsü Dergisi, 20(1), 387-406.

World Bank (2000). Making Transition Work for Everyone: Poverty and Inequality in Europe and Central Asia. Washington D.C: The World Bank Press.

9. Kalkınma Planı (2007-2013). Mükerrer Resmî Gazete Say1: 26215.

http://www.gib.gov.tr/index.php?id=1367

http://www.atonet.org.tr

http://ec.europa.eu/europe2020/pdf/themes/20_tax_ burden_on_labour.pdf/ 